\title{
A New and Concise Strategy to the Enantioselective Synthesis of (S)-2-Amino-4-Oxo-4-(Pyridine-2-yl) Butanoic Acid from Aspartic Acid
}

\author{
Evanoel Crizanto de Lima, ${ }^{a}$ Paulo G. de Lima, ${ }^{b}$ Carolina C. de Souza, ${ }^{a}$ \\ Marta C. L. S. Maior, ${ }^{a}$ Ayres G. Dias ${ }^{c}$ and Paulo R. R. Costa*,a
}

\author{
${ }^{a}$ Núcleo de Pesquisas de Produtos Naturais, Centro de Ciências da Saúde, Universidade Federal do \\ Rio de Janeiro, 21941-540 Rio de Janeiro-RJ, Brazil \\ ${ }^{b}$ Instituto de Química, Universidade Federal do Rio de Janeiro, \\ 21941-909 Rio de Janeiro-RJ, Brazil \\ 'Instituto de Química, Universidade do Estado do Rio de Janeiro, \\ 22250-040 Rio de Janeiro-RJ, Brazil
}

\begin{abstract}
O $\alpha$-aminoácido $(S)$-5 foi sintetizado usando na etapa chave uma reação de substituição nucleofílica quimiosseletiva entre um diéster derivado do ácido L-aspártico e a 2-lítio piridina. $\mathrm{O}$ rendimento global (13\%, 5 etapas) foi semelhante ao previamente descrito por nosso grupo (12\%, 10 etapas) para obtenção do isômero $R$ (o primeiro agonista pleno exógeno de receptores do sub-tipo NMDA) a partir do D-manitol e ao da síntese racêmica relatada por Lovey e Copper (17\%, 5 etapas).
\end{abstract}

The $\alpha$-amino acid $(S)$-5 was synthesized using in the key step a chemoselective nucleophilic substitution between a diester derived from L-aspartic acid and 2-lithium pyridine. The overall yield (13\%, 5 steps) was similar to those previously described by our group for the $R$ isomer (the first exogen full agonist of the NMDA receptors) from D-mannitol (12\%, 10 steps) and by Lovey and Copper for the racemic synthesis (17\%, 5 steps).

Keywords: stereoselective synthesis, chemoselective acyl substitution, aspartic acid diester, neuroactive amino acid, NMDA, L-tryptophan metabolism

\section{Introduction}

Around $99 \%$ of the essential amino acid L-tryptophan obtained in the diet is metabolized through the kynurenine pathway. Kynurenine (1a) is the first metabolite of tryptophan, being formed by oxidation of the indol ring by enzymes IDO (indoleamine dioxygenase) and TDO (tryptophan-2,3-dioxygenase). This compound can be further transformed by the enzyme KAT (kynurenine aminotransferase) into kynurenic acid, a neuroprotector compound (Figure 1). ${ }^{1}$ On the other hand, the enzyme kynurenine 3-hydroxilase oxidizes 1a into 3-hydroxykynurenine (1b), which is further transformed in quinolinic acid, a neurotoxic agent. Quinolinic acid can be alternatively formed from 1a by the action of kyrureninase. Thus, the inhibition of kyrureninase and kynurenine 3-hydroxylase drives the tryptophan metabolism toward kynurenic acid, leading to neuroprotection. ${ }^{1}$

*e-mail: prrcosta@ism.com.br
It was found that quinolinic acid acts as an agonist at NMDA sub-type of glutamate receptors at the CNS while kynurenic acid acts as an antagonist at the same receptors, suggesting that these pathways could be involved in synaptic plasticity and neurodegeneration. ${ }^{1}$ These pathways are also important in the regulation of cell proliferation and present a multitude of potential sites for drug discovery in neuroscience, oncology and visceral pathology. ${ }^{2}$ Some synthetic analogues of $\mathbf{1 a}$ (compounds 2-4, Figure 1) showed to be strong inhibitors of kynureninase, ${ }^{1}$ significantly increasing the brain content of kynurenic acid and preventing the induction of seizures.

Some years ago compound $(R)-5$ (Figure 2) was tested on NMDA receptors from rat neurons in culture, using the patch-clamp electrophysiological technique. Whole-cell currents evoked by NMDA $\left(10 \mu \mathrm{mol} \mathrm{L}^{-1}\right)$ were potentiated by the natural co-agonist glycine and also by $(R)-\mathbf{5}$ in a concentration-dependent manner. When compared to glycine in the same cells, $(R)-\mathbf{5}$ showed the same maximal response, but lower potency (50x larger 
<smiles>Nc1cccc(C(=O)C[C@H](N)C(=O)O)c1</smiles>

a: $\mathrm{R}^{1}=\mathrm{H} ; \mathbf{b}: \mathrm{R}^{1}=\mathrm{OH}$<smiles>NC(CC(=O)c1ccc2ccccc2c1)C(=O)O</smiles>

3<smiles>N[C@@H](CC(=O)c1cccnc1)C(=O)O</smiles>

2<smiles>[R7]c1ccc(C(=O)CC(N)C(=O)O)cc1[R]</smiles>

a: $\mathrm{R}^{1}=\mathrm{NO}_{2}, \mathrm{R}^{2}=\mathrm{H} ; \mathbf{b}: \mathrm{R}^{1}=\mathrm{R}^{2}=\mathrm{Cl}$

Figure 1. Kynurenine (1a), 3-hydroxykinurenine (1b) and analogues.

mean effective concentration). ${ }^{3,4}$ These data suggest that $(R)-5$ interacts with the glycine site (GlyB) of the NMDA and is the first exogen full agonist of this receptor described in the literature. ${ }^{3,4}$ Confirming this view, currents induced by co-application of NMDA and $(R)-5$ were blocked by the selective GlyB antagonist 5,7-dichlorokynurenic acid (5,7-DCKA $\left.1 \mu \mathrm{mol} \mathrm{L}^{-1}\right){ }^{4}$<smiles>N[C@@H](CC(=O)c1ccccn1)C(=O)O</smiles>

(S) -5<smiles>COC(=O)C[C@H](NC(=O)OCc1ccccc1)C(=O)O</smiles>

6, $\mathrm{R}=\mathrm{H}$ 7, $\mathrm{R}={ }^{\mathrm{t}} \mathrm{Bu}$<smiles>[R]C1CC2(OC)O[C]([Al]1)N2C(=O)OC(C)(C)C</smiles>

a: $\mathrm{R}=\mathrm{CO}_{2} \mathrm{Li}$ b: $\mathrm{R}=\mathrm{CO}_{2}{ }^{\mathrm{t}} \mathrm{Bu}$

Figure 2. Compounds prepared in this work (5-7) and intermediates proposed for the key step.

Compound ( $R$ )-5 (unnatural D-configuration), was designed and previously prepared by our group from an enoate derived from D-mannitol, ${ }^{3}$ in $12 \%$ overall yield after 10 steps. $^{3}$ However, to obtain its enantiomer using the same strategy, the starting chiral enoate should be prepared from vitamin $\mathrm{C}$, in more steps and lower yield. ${ }^{5}$ Lovey and Copper also synthetized $\mathbf{5}$ in 5 steps and 17\% overall yield, however the $\alpha$-amino acid was obtained in its racemic form. ${ }^{6,7}$

The biological importance of $(R)-\mathbf{5}$ as a neuroactive compound makes its synthesis a relevant task. In order to have a shorter enantioselective synthesis for this type of amino acid in both $R$ and $S$ configuration, we decided to use aspartic acid as starting material. We describe in this paper our efforts on the preparation of $(S)-\mathbf{5}$ from more inexpensive L-aspartic acid. The key step proposed in this synthesis is a chemoselective nucleophilic substitution at a $\mathrm{C} 4$ methylester group in $\mathbf{6}$ and $\mathbf{7}$ by 2-lithiumpyridine, leading to a stable six membered chelated intermediates $(\mathbf{I a}, \mathbf{b})$ which could be transformed into the corresponding ketone after workup (Figure 2). The role of $\beta$-amino groups in the control of the reaction course of an ester group toward ArLi species was previously described by our group in the synthesis of $(R)-\mathbf{5}$ from D-mannitol. ${ }^{3}$

\section{Results and Discussion}

The chemical differentiation between the two carboxyl groups in aspartic acid is a key step to use this chiron, commercially available in L and D configuration, as starting material in organic synthesis. ${ }^{8}$ The monomethyl ester $\mathbf{6}$ and the diester 7 (Figure 2) were designed as appropriate intermediates for the syntheses of amino acids type $\mathbf{4}$ through chemoselective nucleophilic acyl-substitution and were easily prepared from aspartic acid. ${ }^{8,10}$

We firstly used compound $\mathbf{6}$ as starting material, avoiding the steps of protection and deprotection at $\mathrm{C} 1$ acid group, which are required in the approach using 7 . We realize that in basic medium the carboxy group in this intermediate would be transformed into the carboxylate, providing in situ protection of this group toward nucleophiles (Scheme 1). Firstly, we carried out the reaction using ${ }^{\mathrm{B}} \mathrm{BuLi}$ as a model and $\mathbf{6}$ in THF at $-78{ }^{\circ} \mathrm{C}$, which led to ketone $\mathbf{8}$ in $38 \%$ yield. The formation of tertiary alcohol was not observed in the crude product. This ketone was transformed to corresponding methyl ester 9 with diazomethane (100\%) to prove that the addition had occurred chemoselectively at carbonyl group $\mathrm{C} 1$ and the Boc group had been removed 


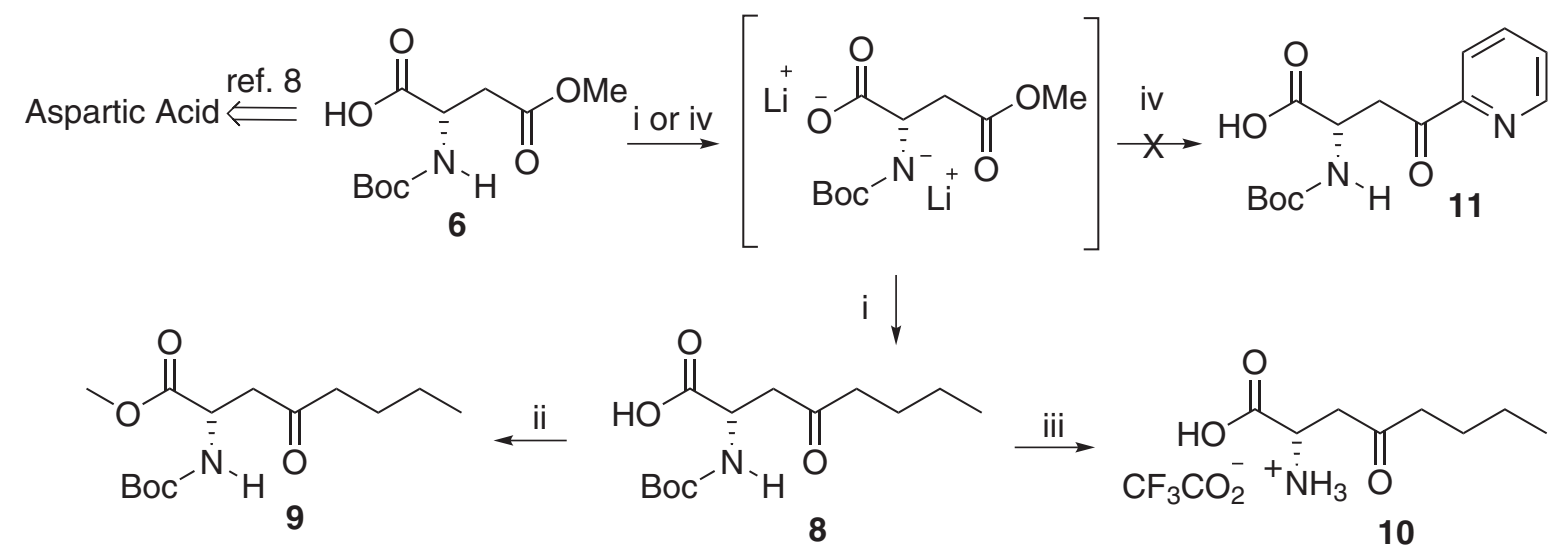

i) a) ${ }^{n} \mathrm{BuLi}, \mathrm{THF},-78^{\circ} \mathrm{C}$, b) $\mathrm{AcOH}, \mathrm{THF}, 38 \%$; ii) $\mathrm{CH}_{2} \mathrm{~N}_{2}, \mathrm{MeOH}, 100 \%$; iii) $\mathrm{TFA} / \mathrm{H}_{2} \mathrm{O}, 90 \%$; iv) 2-LiPy, $\mathrm{THF},-78{ }^{\circ} \mathrm{C}$, b) AcOH, THF, a complex mixture of products

Scheme 1. Attempt to prepare ketone $\mathbf{1 1}$ from $\mathbf{6}$ after optimization of chemoselective addition of ${ }^{\mathrm{B}} \mathrm{BuLi}$ to $\mathbf{6}$.

leading to amino acid 10. After these encouraging results, we tried the addition of 2-lithiumpyridine to monoester 6 under the same conditions to obtain $\mathbf{1 1}$, but unfortunately a complex mixture of products was formed in this case.

Our next goal was to use diester $(S)-7$ to obtain amino acid $(S)$-5. This compound was prepared from $N$-Boc derivative $(S)-\mathbf{6}$ by esterification with tert-butanol in the presence of DCC (Scheme 2). ${ }^{9}$ The carboxy group in $\mathbf{6}$ presented low reactivity, requiring the use of 10 equiv. of tert-butanol to consume all starting material. Diester $(S)$-7 was then allowed to react with 2-lithiumpyridine at $-78^{\circ} \mathrm{C}$ leading to the product of chemoselective nucleophilic acyl substitution at the methyl ester group (S)-13, after acidic<smiles>COC(=O)CC(NC(=O)OC(C)(C)C)C(=O)O</smiles><smiles>CCC(C)OC(=O)N[C@@H](CC(=O)OC)C(=O)OC(C)(C)C</smiles>

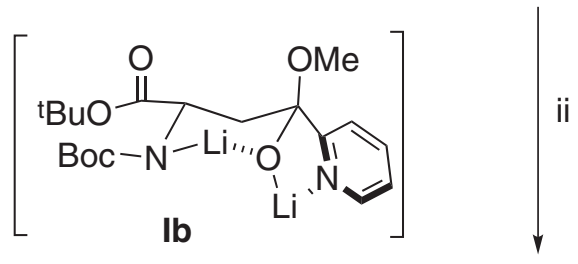<smiles>C#C[AsH3]</smiles><smiles>CCC(C)OC(=O)N[C@@H](CC(=O)c1ccccn1)C(=O)OC(C)(C)C</smiles>

12

i) 'BuOH, DCC, DMAP, $\mathrm{CH}_{2} \mathrm{Cl}_{2}, 70 \%$; ii) a) 2-LiPy, THF; b) AcOH, THF, $38 \%$; iii) $\mathrm{TFA} / \mathrm{H}_{2} \mathrm{O}, 78 \%$

Scheme 2. Synthesis of amino acid 5 from $(S)$-6. work-up. Also in this case the formation of tertiary alcohol was not observed in the crude product. The intermediate $\mathbf{I b}$ is proposed to explain the exclusive formation of ketone 12. The corresponding amino acid $(S)-\mathbf{5}$ was prepared as a salt by protecting group cleavage using trifluoracetic acid and $\mathrm{H}_{2} \mathrm{O}$ in a 9:1 mixture.

\section{Conclusions}

Amino acid ( $S$ )-5 was prepared from commercially available aspartic acid in $12 \%$ overall yield in 5 steps, improving its stereoselective synthesis. Our approach allows the syntheses of both $R$ and $S$ enantiomers of $\mathbf{5}$ from the commercially available $\mathrm{D}$ and $\mathrm{L}$ aspartic acids, respectively.

\section{Experimental}

\section{(S)- 4-Methyl N-tert-butoxycarbonyl aspartate, 6}

Compound 6 was prepared according to literature. ${ }^{8,10}$ ${ }^{1} \mathrm{H}$ NMR (200 MHz, $\left.\mathrm{CDCl}_{3}\right) \delta(\mathrm{ppm}): 4.42-4.34(1 \mathrm{H}, \mathrm{m})$, $3.62(3 \mathrm{H}, \mathrm{s}), 2.89(1 \mathrm{H}, \mathrm{dd}, J 16.6 \mathrm{~Hz}, 4.4 \mathrm{~Hz}), 2,70(1 \mathrm{H}$, dd, $J 16.6 \mathrm{~Hz}, 5.0 \mathrm{~Hz}), 1.3 \mathrm{~s}(9 \mathrm{H}, \mathrm{s})$.

\section{(S)-1-tert-Butyl-4-methyl N-tert-butoxycarbonyl aspartate, $7^{10}$}

To a solution of monomethyl ester $\mathbf{6}(1.87 \mathrm{~g}, 7.46 \mathrm{mmol})$ in dichlorometane $(40 \mathrm{~mL})$ were added tert-butanol ( $74.6 \mathrm{mmol})$ and DMAP $(0.75 \mathrm{mmol})$. DCC $(9.70 \mathrm{mmol})$ was added at the reaction mixture at $0{ }^{\circ} \mathrm{C}$, which was then stirred $5 \mathrm{~min}$ at $0^{\circ} \mathrm{C}$ and overnight at room temperature. Precipitated urea was filtered off and the solvent was removed by 
evaporation in vacuo. The residue was purified by flash chromatography (ethyl acetate/hexane, 1:9) affording 7 as a solid (1.56 g, 70\%). ${ }^{1} \mathrm{H}$ NMR (200 MHz, $\left.\mathrm{CDCl}_{3}\right) \delta(\mathrm{ppm})$ : 4.48-4.20 (1H, m), $3.71(3 \mathrm{H}, \mathrm{s}), 2.97(1 \mathrm{H}, \mathrm{dd}, J 17.9 \mathrm{~Hz}$, $4.4 \mathrm{~Hz}), 2.77$ (1H, dd, J 17.9 Hz, $4.8 \mathrm{~Hz}), 1.47$ (18H, s).

\section{(S)-2-N-tert-Butoxycarbonyl-4-oxooctanoic acid, 8}

To a solution of monoester $\mathbf{6}(0.24 \mathrm{~g} ; 0.97 \mathrm{mmol})$ in THF $(1.95 \mathrm{~mL})$ at $-78^{\circ} \mathrm{C}{ }^{\mathrm{n}} \mathrm{BuLi} 1.6 \mathrm{M}(3.9 \mathrm{mmol})$ was slowly added. After $3 \mathrm{~h}$, the reaction was quenched with $\mathrm{AcOH} 20 \%$ $\mathrm{v} / \mathrm{v}$ in THF. The medium was neutralized with $\mathrm{NaHCO}_{3}$ $10 \%$, the aqueous phase was separated, and extracted with AcOEt. The organic layer was dried over anhydrous $\mathrm{Na}_{2} \mathrm{SO}_{4}$ and the solvent was removed by evaporation in vacuo to give $8(0.10 \mathrm{~g}, 38 \%)$. $[\alpha]_{\mathrm{D}}=-6.8^{\circ}\left(\mathrm{c} 1.8, \mathrm{CHCl}_{3}\right) ;{ }^{1} \mathrm{H} \mathrm{NMR}$ $\left(200 \mathrm{MHz}, \mathrm{CDCl}_{3}\right) \delta(\mathrm{ppm}): 5.58(1 \mathrm{H}, \mathrm{s}), 4.54(1 \mathrm{H}, \mathrm{m})$, $3.19(1 \mathrm{H}, \mathrm{dd}, J 18.0 \mathrm{~Hz}, 3.6 \mathrm{~Hz}), 2.95(1 \mathrm{H}, \mathrm{dd}, J 18.0 \mathrm{~Hz}$, $3.8 \mathrm{~Hz}), 2.43(2 \mathrm{H}, \mathrm{t}, J 7.2 \mathrm{~Hz}), 1.44(9 \mathrm{H}, \mathrm{s}), 1.60-1.25(4 \mathrm{H}$, m), $0.90(3 \mathrm{H}, \mathrm{t}, J 7.2 \mathrm{~Hz})$.

(S)-1-tert-Butyl-N-tert-butoxycarbonyl-4-oxo-4-(pyridin2-yl) butanoate, 12

${ }^{\text {nBuLi }} 3.13 \mathrm{~mol} \mathrm{~L}^{-1}(1.2 \mathrm{~mL} ; 3.76 \mathrm{mmol})$ was cooled at $-78{ }^{\circ} \mathrm{C}$ and diluted with $10 \mathrm{~mL}$ THF. A solution of 2-bromopyridine $(0.35 \mathrm{~mL} ; 3.66 \mathrm{mmol})$ in THF $(3.6 \mathrm{~mL})$ was then slowly added. After $15 \mathrm{~min}$, a solution of diester 7 $(0.32 \mathrm{~g} ; 1.05 \mathrm{mmol})$ in THF $(2.6 \mathrm{~mL})$ was added dropwise. After $3 \mathrm{~h}$ the reaction was quenched with $\mathrm{AcOH} 20 \% \mathrm{v} / \mathrm{v}$ in THF. The medium was neutralized with $\mathrm{NaHCO}_{3} 10 \%$, the aqueous phase was separated, and extracted with AcOEt. The organic layer was dried over anhydrous $\mathrm{Na}_{2} \mathrm{SO}_{4}$ and the solvent was removed by evaporation in vacuo. After flash chromatography (ethyl acetate/hexane, 1:9), 12 was obtained in $38 \%$ yield as viscous oil $(0.14 \mathrm{~g})$. $[\alpha]_{\mathrm{D}}=-2.34^{\circ}$ (c 1.71, $\mathrm{CHCl}_{3}$ ); ${ }^{1} \mathrm{H}$ NMR (200 MHz, $\left.\mathrm{CDCl}_{3}\right) \delta$ (ppm): 8.70 $(1 \mathrm{H}, \mathrm{d}), 8.01(1 \mathrm{H}, \mathrm{d}), 7.84(1 \mathrm{H}, \mathrm{t}), 7.49(1 \mathrm{H}, \mathrm{t}), 4.67-4.63$ $(1 \mathrm{H}, \mathrm{m}), 3.88(1 \mathrm{H}, \mathrm{dd}, J 18.1 \mathrm{~Hz}, 5.0 \mathrm{~Hz}), 3.65(1 \mathrm{H}, \mathrm{dd}, J$ $18.1 \mathrm{~Hz}, 4.5 \mathrm{~Hz}), 1.41(18 \mathrm{H}, \mathrm{s}) .{ }^{13} \mathrm{C} \mathrm{NMR}\left(50 \mathrm{MHz}, \mathrm{CDCl}_{3}\right)$ $\delta$ (ppm): 199.4, 170.6, 155.5, 152.8, 149.0, 136.8, 127.3, 121.6, 81.8, 50.2, 40.4, 29.6, 28.2, 27.6.

\section{(S)-2-Amino-4-oxo-4-(pyridin-2-yl) butanoic acid, 5}

Ketone $12(0.08 \mathrm{~g})$ was dissolved in a mixture of trifluoroacetic acid-water (9:1). The resulting solution was stirred for $5 \mathrm{~h}$ and the solvent was evaporated in vacuo to furnish amino acid $(S)-5$ in $78 \%$ yield $(0.055 \mathrm{~g})$, as the corresponding monotrifluoroacetate salt (viscous oil). $[\alpha]_{\mathrm{D}}=+8.8^{\circ}\left(\mathrm{c} 1.4, \mathrm{CH}_{3} \mathrm{OD}\right) ;{ }^{1} \mathrm{H} \mathrm{NMR}\left(200 \mathrm{MHz}, \mathrm{CH}_{3} \mathrm{OD}\right)$ $\delta(\mathrm{ppm}): 8.73(1 \mathrm{H}, \mathrm{d}), 8.12(1 \mathrm{H}, \mathrm{d}), 8.01(1 \mathrm{H}, \mathrm{t}), 7.67$ $(1 \mathrm{H}, \mathrm{t}), 4.54-4.49(1 \mathrm{H}, \mathrm{m}), 3.98-3.92(2 \mathrm{H}, \mathrm{m}) ;{ }^{13} \mathrm{C} \mathrm{NMR}$ $\left(50 \mathrm{MHz}, \mathrm{CDCl}_{3}\right) \delta(\mathrm{ppm}): 198.7,171.4,153.3,150.5$, $138.8,129.9,129.5,123.1,76.7,38.8,30.8,17.7$.

\section{Supplementary Information}

Supplementary data are available free of charge at http://jbcs.sbq.org.br, as PDF file.

\section{Acknowledgments}

Financial supports were provided by CAPES, FAPERJ, CNPq and FINEP. Evanoel Crizanto de Lima and Paulo R. R. Costa thank to CNPq and Ayres G. Dias thanks to UERJ for fellowships. The authors also thank professor Alessandro B. C. Simas for helpful suggestions.

\section{References}

1. Schwarcz, R.; Young, S. N.; Brown, R. R.; Kynurenine and Serotonin Pathways: Progress in Tryptophan Research, $6^{\text {th }}$ ed., Plenum: New York, 1991; Stone, T. W.; Pharmacol Rev. 1993, 45, 309; Schwarcz, R.; Curr. Opin. Pharmacol. 2004, 4, 12; Stone, T. W.; Prog. Neurobiol. 2001, 64, 185; Stone, T. W.; Trends Pharmacol. Sci. 2000, 21, 149.; Pellicciari, R.; Natalini, B.; Costantino, G.; Mahmoud, M. R.; Mattoli, L.; Sadeghpour, B. M.; J. Med. Chem. 1994, 37, 647; Millan, M. J.; Psychopharmacology 2005, 179, 30.

2. Stone, T. W.; Darlington, L. G.; Nat. Rev. Drug Discovery 2002 , 1,609 .

3. Lima, P. G.; Sequeira, L. C.; Costa, P. R. R.; Tetrahedron Lett. 2001, 42, 3525; Lima, P. G.; Caruso, R. R. B.; Alves, S. O.; Pessôa, R. F.; Mendonça-Silva, D. L.; Nunes, R. J.; Noël, F.; Castro, N. G.; Costa, P. R. R.; Bioorg. Med. Chem. Lett. 2004, 14, 4399.

4. Caruso, R. R. B.; PhD Thesis, Universidade Federal do Rio de Janeiro, Brazil, 2007.

5. Hubschwerlin, C.; Synthesis 1986, 962.; Mikkilineni, A. B.; Kumar, P.; Abushanab, E.; J. Org. Chem. 1988, 53, 6005.; de Lima, E. C.; Synlett 2009, 1861.

6. Lovey, R. G.; Cooper, A. B.; Synlett 1994, 167.

7. Anothers analogues have also prepared in the literature: Pellicciari, R.; Gallo-Mezo, M. A.; Natalini, B.; Amer, A. M.; Tetrahedron Lett. 1992, 33, 3003; Rilatt, I.; Caggiano, L.; Jackson, R. F. W.; Synlett 2005, 2701; Deguest, G.; Bischoff, L.; Fruit, C.; Marsais, F.; Tetrahedron: Asymmetry 2006, 17, 2120; Golubev, A. S.; Sewald, N.; Burger, K.; Tetrahedron 1996, 52, 14757; Melillo, D. G.; Larsen, R. D.; Mathre, D. J.; Shukis, W. F.; Wood, A. W.; Colleluori, J. R.; J. Org. Chem. 1987, 52, 5143. 
8. Gmeiner, P.; Feldman, P. L.; Chu-Moyer, M. Y.; Rapoport, H.; J. Org. Chem. 1990, 55, 3068; Sardina, F. J.; Rapoport, H.; Chem. Rev. 1996, 96, 1825; Berrée, F.; Chang, K.; Cobás, A.; Rapoport, H.; J. Org. Chem. 1996, 61, 715; Bergmeier, S. C.; Cobás, A. A.; Rapoport, H.; J. Org. Chem. 1993, 58, 2369; Cox, R. J.; Hadfield, A. T.; Mayo-Martín, M. B.; Chem. Commun. 2001, 1710.
9. Neises, B.; Steglich, W.; Angew. Chem., Int. Ed. 1978, 17, 522.; Hassner, A.; Alexanian, V.; Tetrahedron Lett. 1978, 46, 4475.

10. Ramalingam, K.; Woodward, R. W.; J. Org. Chem. 1988, 53 , 1900.

Received: December 2, 2009 Web Release Date: March 4, 2010 


\section{A New and Concise Strategy to the Enantioselective Synthesis of (S)-2-Amino-4-Oxo-4-(Pyridine-2-yl) Butanoic Acid from Aspartic Acid}

\section{Evanoel Crizanto de Lima, ${ }^{a}$ Paulo G. de Lima, ${ }^{b}$ Carolina C. de Souza, ${ }^{a}$ \\ Marta C. L. S. Maior, ${ }^{a}$ Ayres G. Dias ${ }^{c}$ and Paulo R. R. Costa ${ }^{*, a}$}

${ }^{a}$ Núcleo de Pesquisas de Produtos Naturais, Centro de Ciências da Saúde, Universidade Federal do Rio de Janeiro, 21941-540 Rio de Janeiro-RJ, Brazil

${ }^{b}$ Instituto de Química, Universidade Federal do Rio de Janeiro, 21941-909 Rio de Janeiro-RJ, Brazil

'Instituto de Química, Universidade do Estado do Rio de Janeiro, 22250-040 Rio de Janeiro-RJ, Brazil<smiles>COC(=O)C[C@H](NC(=O)OCc1ccccc1)C(=O)O</smiles>

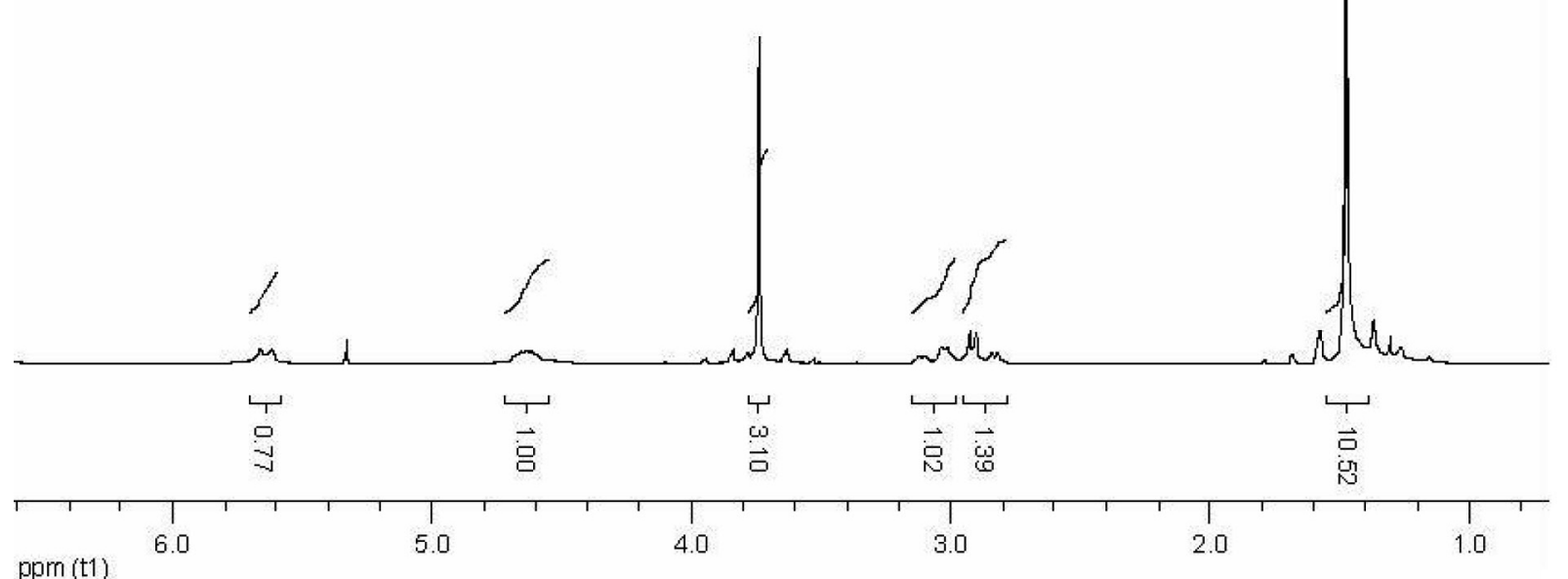

Figure S1. ${ }^{1} \mathrm{H}$ NMR Spectrum of compound 6. 
<smiles>COC(=O)C[C@H](NC(=O)OC(C)(C)C)C(=O)OC(C)(C)C</smiles>

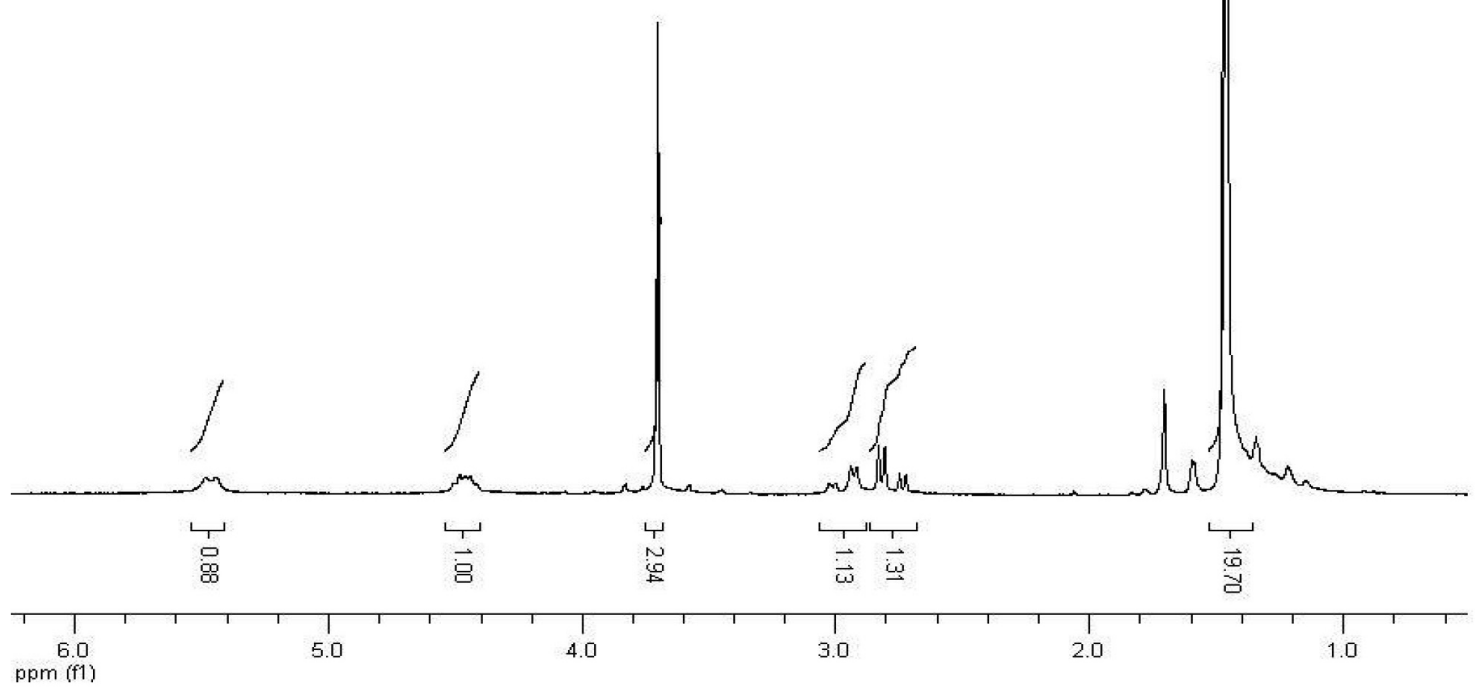

Figure S2. 'H NMR Spectrum of compound 7.<smiles>CC(C)(C)OC(=O)N[C@@H](CC(=O)c1ccccn1)C(=O)OC(C)(C)C</smiles>

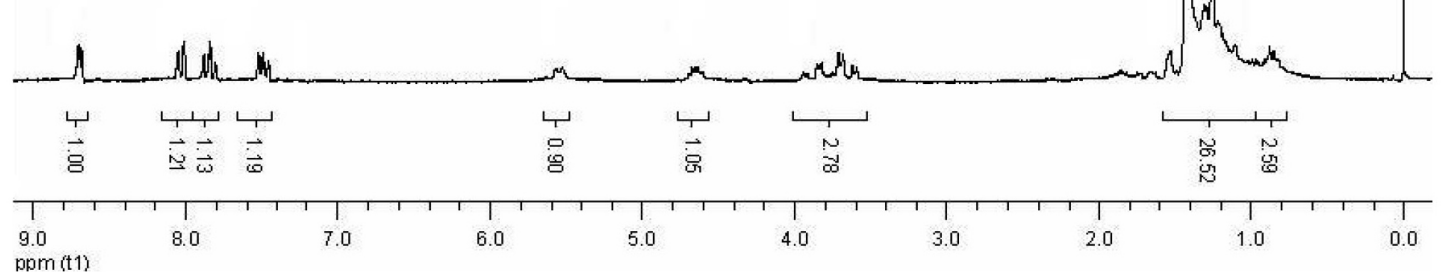

Figure S3. ${ }^{1} \mathrm{H}$ NMR Spectrum of compound 13. 


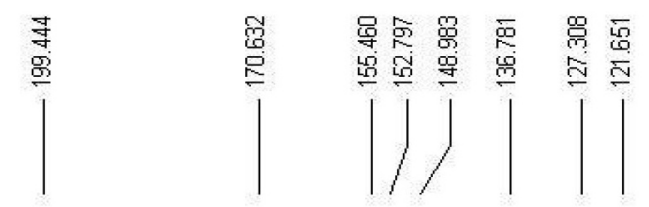<smiles>CC(C)(C)OC(=O)NC(=O)[C@@H](CC(=O)c1ccccn1)NC(=O)OC(C)(C)C</smiles>
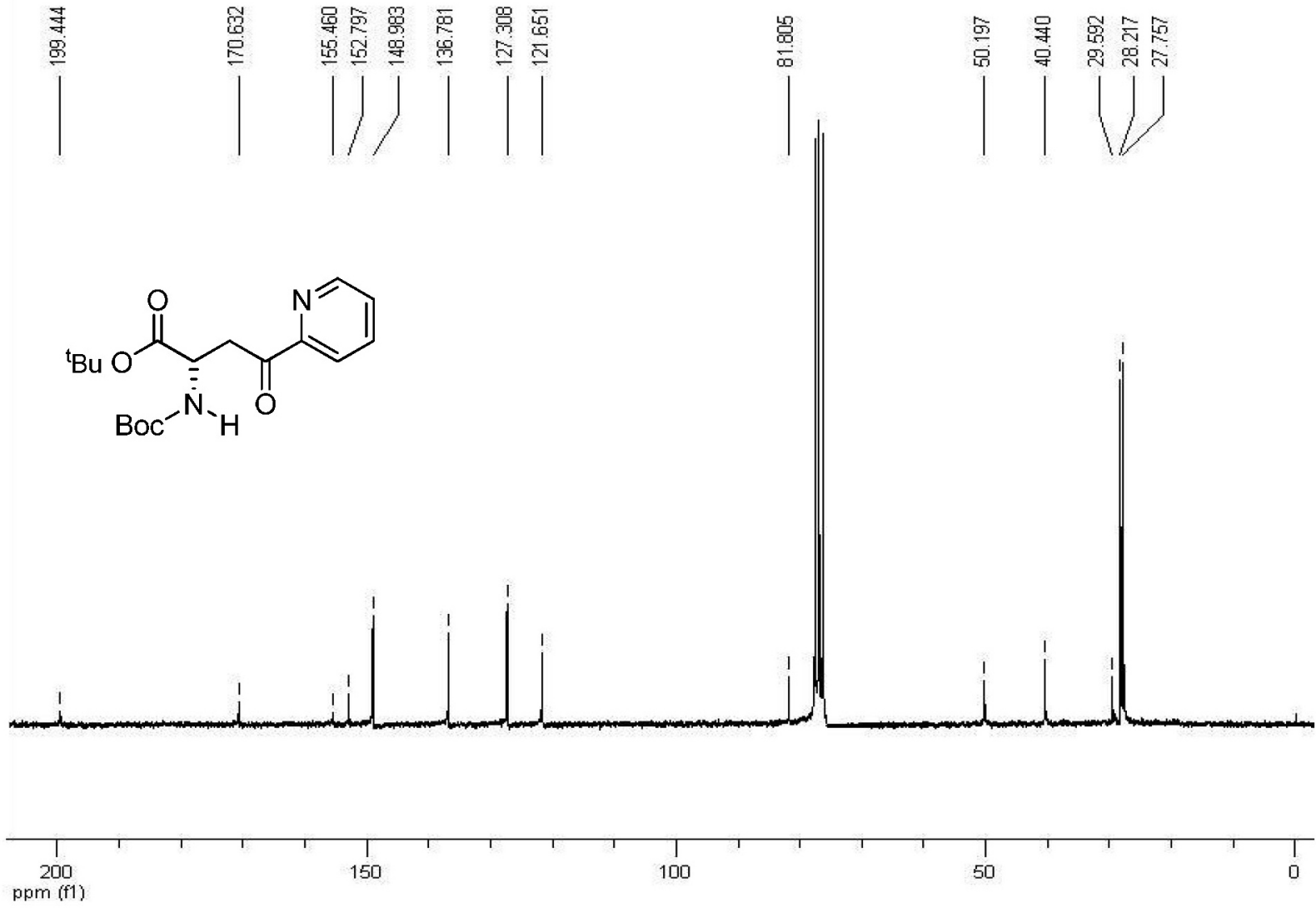

Figure S4. ${ }^{13} \mathrm{C}$ NMR Spectrum of compound $\mathbf{1 3}$. 


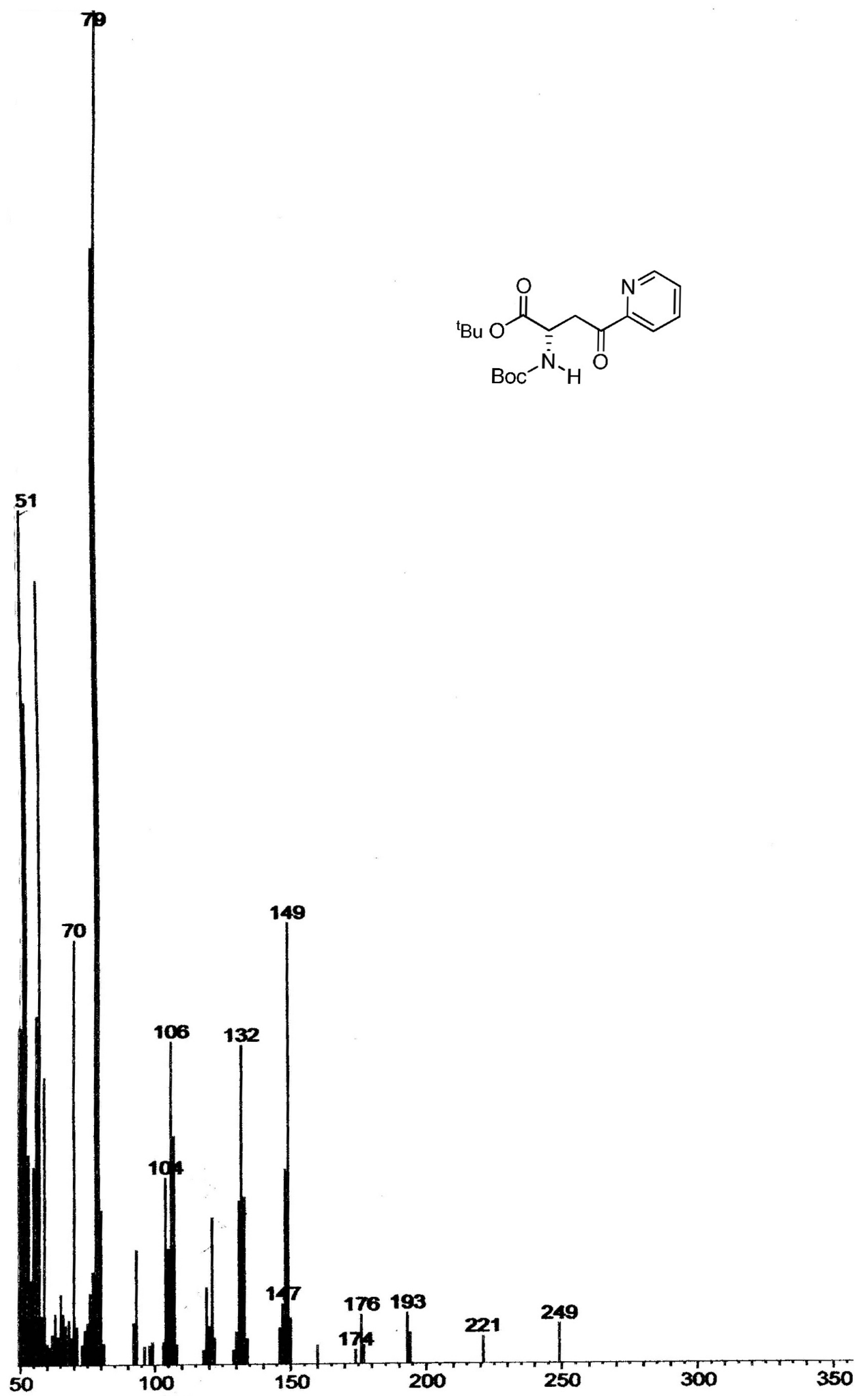

Figure S5. Low resolution mass spectrometry of compound $\mathbf{1 3}$. 
<smiles>O=C(ON[C@@H](CC(=O)c1ccccn1)C(=O)O)OC(F)(F)F</smiles>

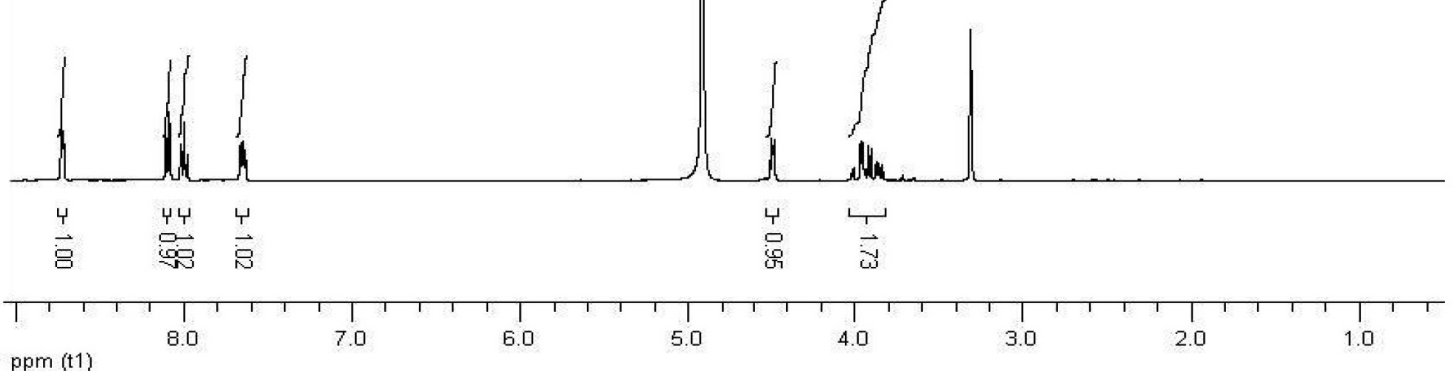

Figure S6. 'H NMR Spectrum of compound 5.

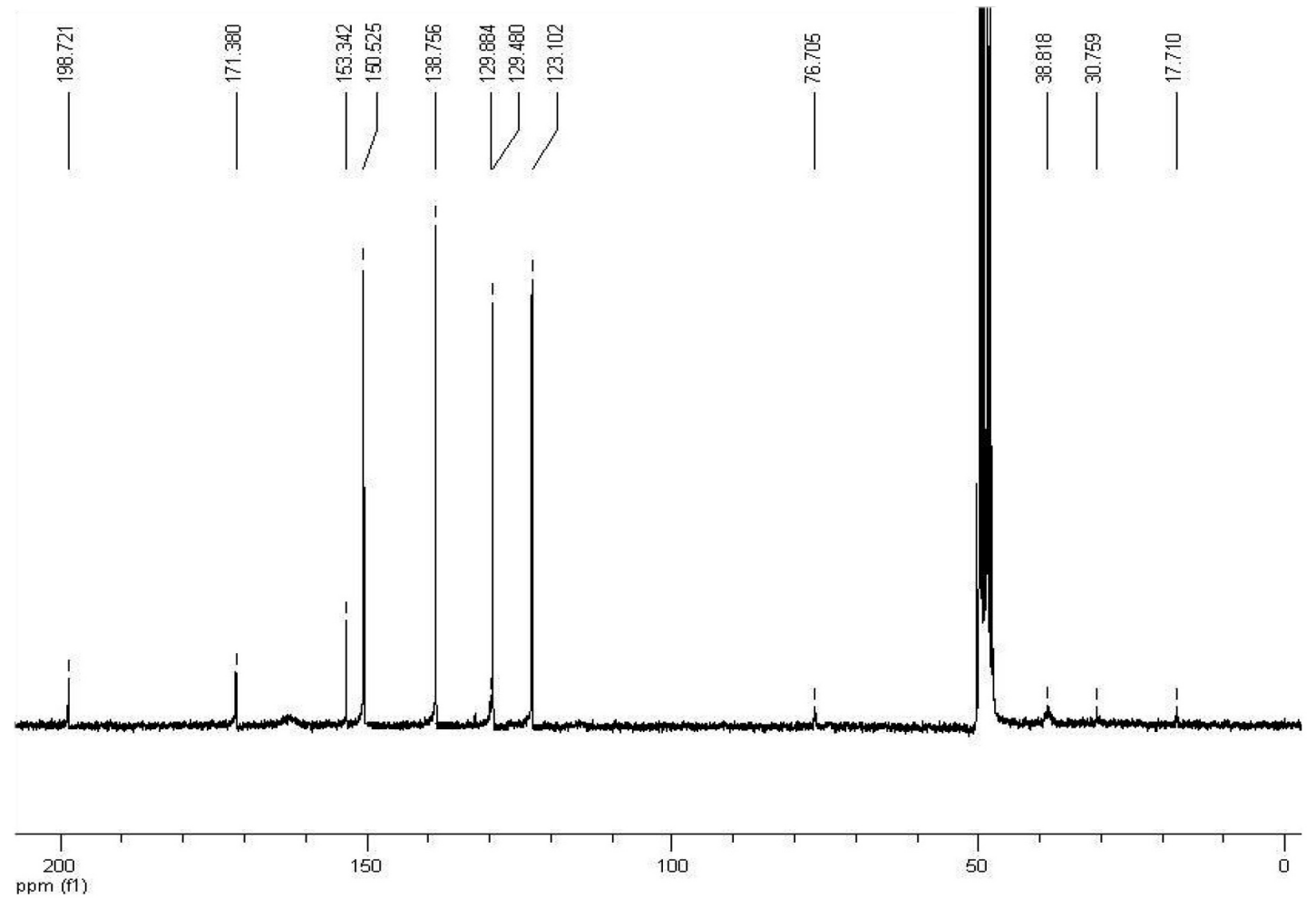

Figure S7. ${ }^{13} \mathrm{C}$ NMR Spectrum of compound 5. 
<smiles>CCCCC(=O)C[C@H](NC(=O)OCc1ccccc1)C(=O)O</smiles>

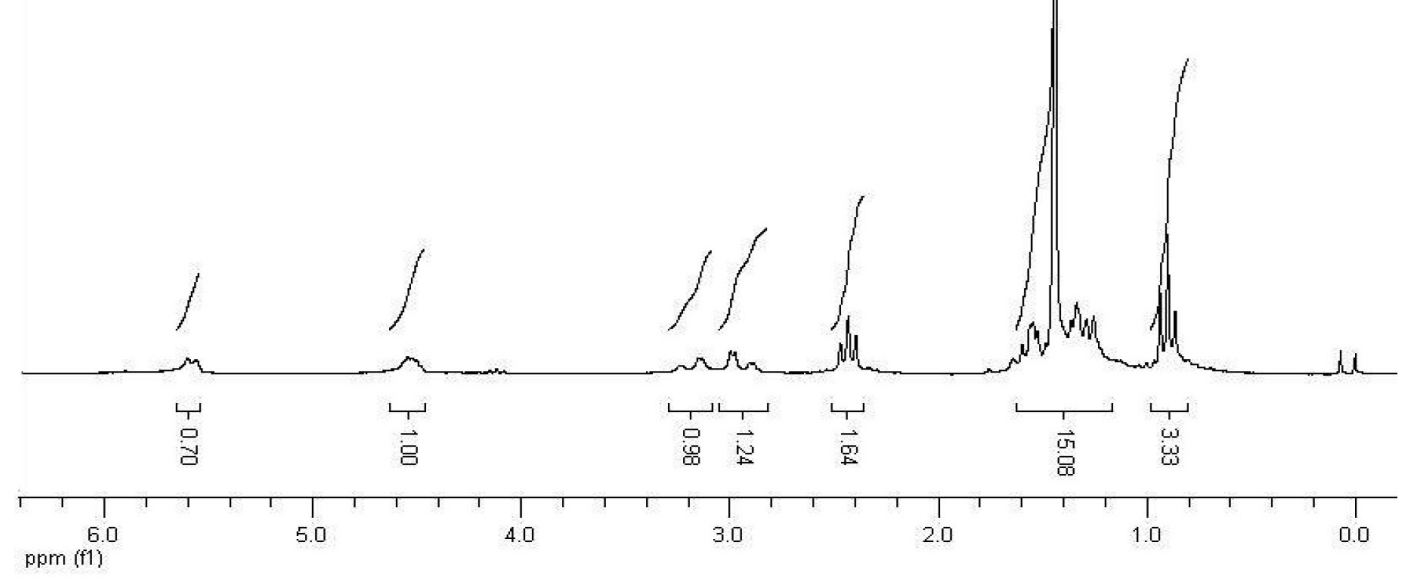

Figure S8. ${ }^{1} \mathrm{H}$ NMR Spectrum of compound $\mathbf{8}$.

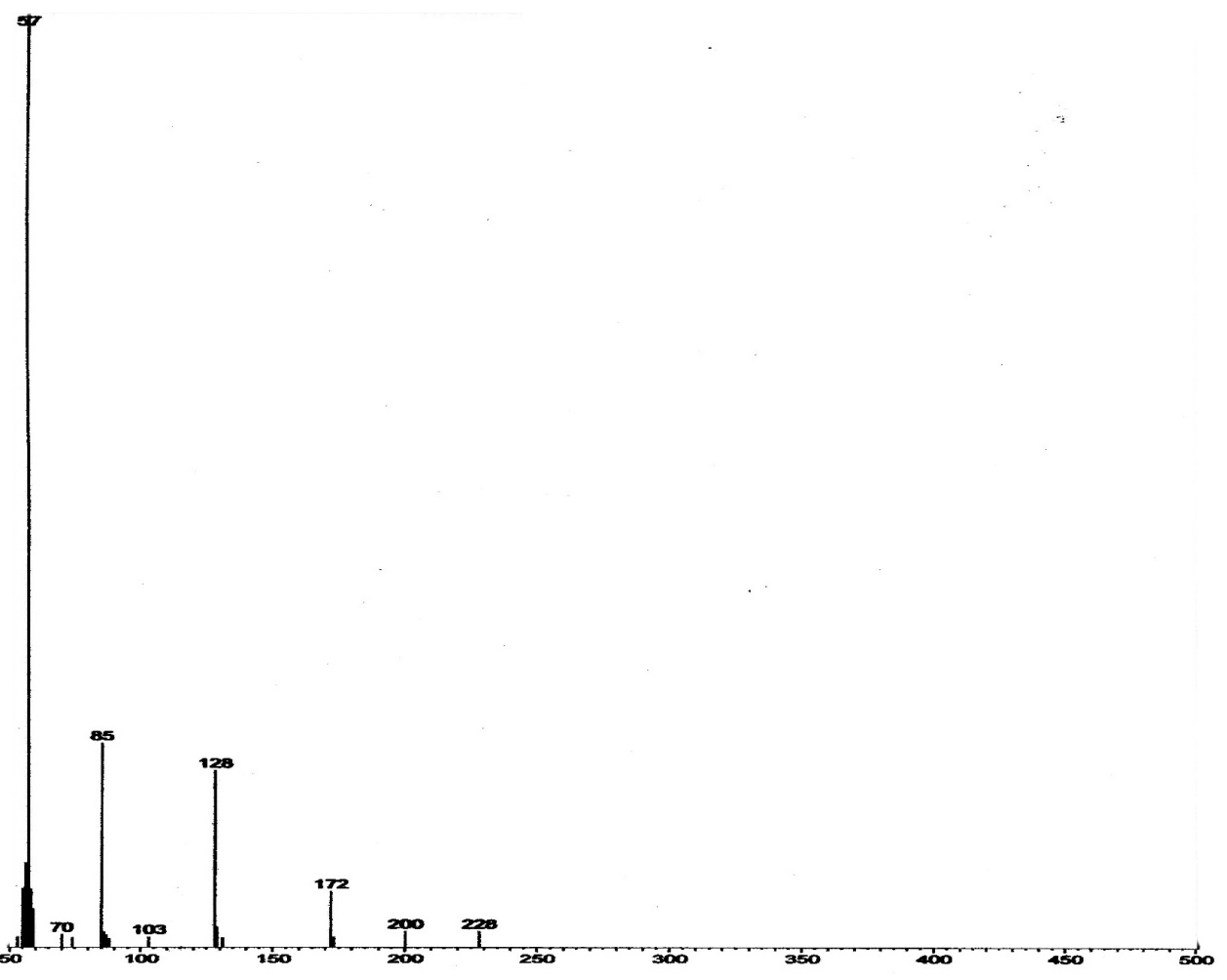

Figure S9. Low resolution mass spectrometry of compound $\mathbf{8}$. 


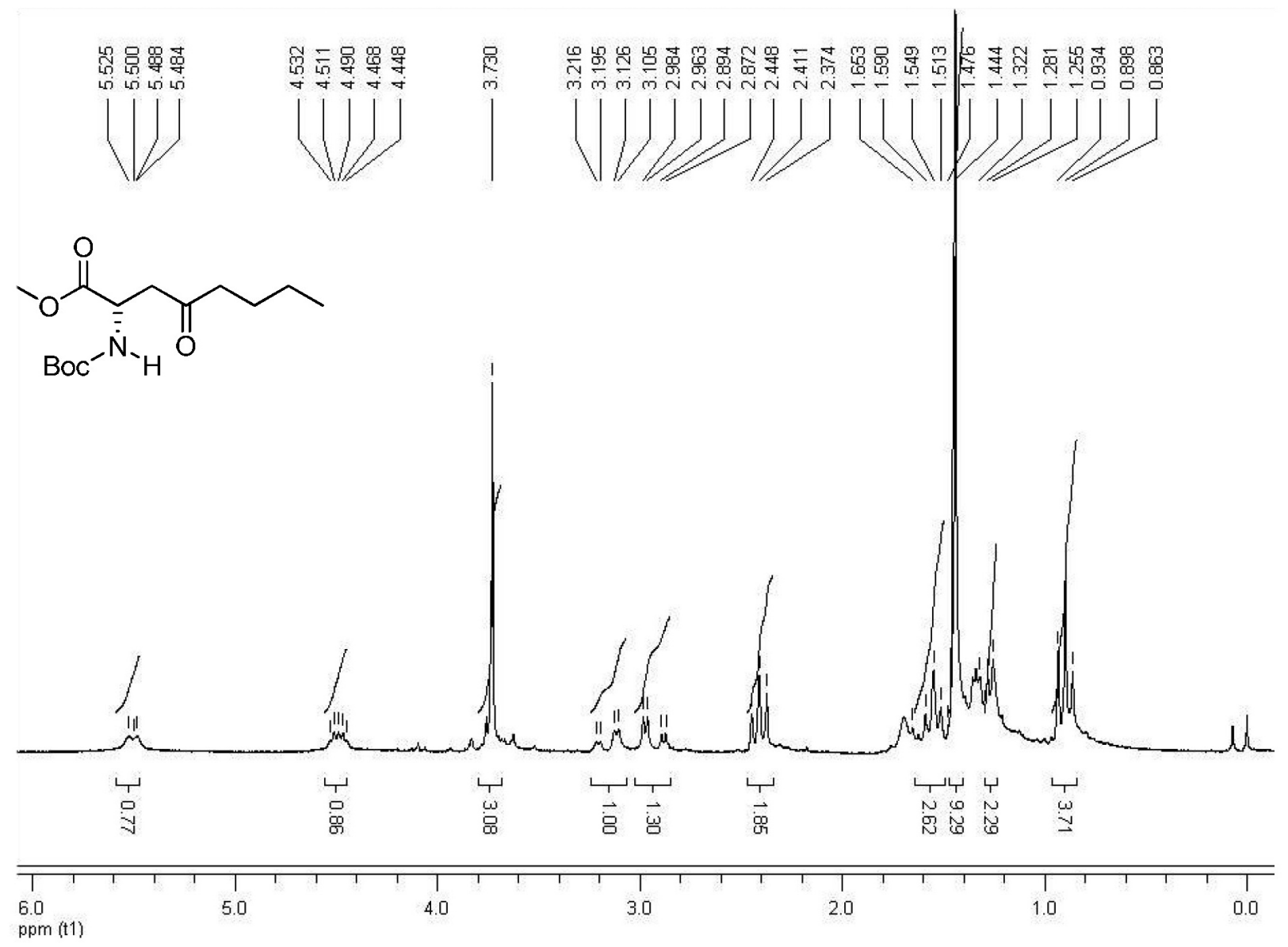

Figure S10. ${ }^{1} \mathrm{H}$ NMR Spectrum of compound 9. 